\title{
Belajar Sejarah Dengan E-Learning Berbasis Discovery Learning
}

\section{Dziky Muhamad Nurcholif1*, I Kadek Suartama ${ }^{2}$, Adrianus I Wayan Ilia Yuda ${ }^{3}$}

\author{
1,2,3 Universitas Pendidikan Ganesha, Singaraja, Indonesia
}

\section{ART I C L E I N F O}

Article history

Received March 10, 2021

Revised March 12, 2021

Accepted July 01, 2021

Available online August 25, 2021

Kata Kunci:

E-Learning, Discovery Learning, Sejarah

Keywords:

E-learning, Discovery learning, History

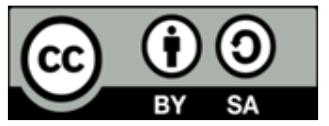

This is an open access article under the CC BY-SA license.

Copyright $₫$ Universitas Pendidikan Ganesha. All rights reserved.

\begin{abstract}
A B S T R A K
Adanya Covid-19 mengharuskan proses pembelajaran dilakukan secara online membuat proses pembelajaran tidak efektif. Penelitian ini bertujuan untuk mengembangkan desain e-learning berbasis discovery learning pada mata pelajaran Sejarah. Penelitian ini merupakan penelitian pengembangan, dengan menggunakan model pengembangan ADDIE. Subjek penelitian yaitu 1 ahli mata pelajaran, 1 ahli desain pembelajaran, 1 ahli media pembelajaran, 3 siswa uji perorangan, dan 9 siswa uji kelompok kecil. Metode pengumpulan data yang digunakan adalah metode pencatatan dokumen dan metode kuesioner. Penelitian pengembangan ini menggunakan dua jenis metode analisis data, yaitu analisis deskriptif kualitatif dan analisis deskriptif kuantitatif. E-learning berbasis discovery learning ini dinyatakan valid dengan hasil review ahli isi mata pelajaran yang menunjukkan e-learning berbasis discovery learning mendapatkan predikat sangat baik $(91 \%)$. Hasil review ahli desain pembelajaran menunjukkan bahwa e-learning berbasis discovery learning ini mendapatkan predikat baik yaitu (83\%). Hasil review dari ahli media pembelajaran menunjukkan e-learning berbasis discovery learning ini mendapatkan predikat sangat baik (92\%). Hasil review dari uji perorangan menunjukkan bahwa e-learning berbasis discovery learning ini mendapatkan predikat sangat baik yaitu (95\%). Hasil review dari uji kelompok kecil menunjukkan e-learning berbasis discovery learning ini mendapatkan predikat sangat baik (93\%). Semua hasil ini menunjukan bahwa e-learning berbasis discovery learning mampu meningkatkan minat belajar siswa pada mata pelajaran Sejarah, sehingga konten e-learning berbasis discovery learning efektif digunakan dalam proses pembelajaran.
\end{abstract}

\section{A B S TRACT}

The existence of Covid-19 requires the learning process to be carried out online, making the learning process ineffective. This research is a development research, using the ADDIE development model. The research subjects were 1 subject expert, 1 learning design expert, 1 learning media expert, 3 individual test students, and 9 small group test students. The data collection methods used are document recording methods and questionnaire methods. This development research uses two types of data analysis methods, namely qualitative descriptive analysis and quantitative descriptive analysis. Discovery learning-based e-learning is declared valid by: (a) the results of a review by subject matter experts which show that discovery learning-based e-learning gets a very good predicate (91\%). (b) the results of the review of learning design experts show that discovery learning-based e-learning gets a good predicate, namely (83\%) (c) the review results from learning media experts show that discovery learning-based e-learning gets a very good predicate (92\%). (d) the results of the review from the individual test show that this discovery learning-based e-learning gets a very good predicate, namely (95\%). (e) the results of the review of the small group test show that this discovery learning-based elearning gets a very good predicate (93\%). This shows that discovery learning-based e-learning is able to increase student interest in history subjects so that discovery learning-based e-learning content is effectively used in the learning process.

\section{PENDAHULUAN}

Covid-19 mengharuskan seluruh proses pembelajaran dilakukan secara online. Dengan adanya pembelajaran online siswa dapat melakukan pembelajaran dimana saja dan kapan saja melalui beberapa 
platform yang tersedia di-internet. Alat e-learning yang mudah digunakan dan dapat membantu meningkatkan minat belajar siswa serta meningkatkan keterampilan indentifikasi siswa (Mitra et al., 2021; Nursulistyo et al., 2021). Hal ini menunjukkan bahwa kehadiran guru di sekolah bukanlah hal yang mutlak dalam proses pembelajaran. Dengan menggunakan media e-learning pembelajaran di sekolah dan pelatihan lainya sudah tidak lagi terpaku dengan kehadiran di kelas, sehingga proses pembelajaran akan dengan mudah diakses oleh siswa (Ali et al., 2021). Kurangnya waktu dalam proses pembelajaran mampu diantisipasi melalui pembelajaran online, terutama mata pelajaran yang memiliki materi banyak, seperti Sejarah. Mata pelajaran Sejarah adalah salah satu mata pelajaran yang perlu dilakukan secara daring karena materi yang disampaikan condong lebih banyak dan meceritakan masa lampau. Mata pelajaran Sejarah dapat melandasi pendidikan intelektual dan kedisiplinan siswa (Apdelmi, 2019). Untuk menghasilkan pembelajaran Sejarah yang baik dan efisien maka perlu diterapkan sebuah pembelajaran inovatif, sehingga proses pembelajaran lebih berkualitas, tak terbatas ruang dan waktu, dan seluruh materi dapat disampaikan seluruhnya. Jika pembelajaran berlangsung secara efektif dan efisien, dengan ditunjang sarana dan prasarana pendukung, maka kecakapan guru dalam pengelolaan kelas serta penguasaan materi yang cukup memadai maka prestasi hasil belajar peserta didik lebih meningkat (Ulfah \& Lukiastuti, 2018).

Berdasarkan hasil observasi yang dilakukan di kelas X pada tanggal 07 Agustus 2020 di kelas X dengan jumlah siswa sebanyak 22 siswa, hanya dua siswa yang belum memiliki smartphone berbasis Android. Selain belum memiliki smartphone, dua siswa tersebut juga tinggal di Pondok Pesantren dan tidak diperbolehkan membawa smartphone. Meski kini kegiatan belajar mengajar melalui daring (Whatshaap) karena sekolah diliburkan, tentu pembelajaran tidak berlangsung secara maksimal hanya sebatas pemberian materi dan tugas. Materi pelajaran Sejarah begitu banyak, sehingga materi tidak dapat tersampaikan secara maksimal. Pada umumnya proses pembelajaran sejarah diasumsikan masih sangat kurang efektif, terutama pada proses pembelajaran di kelas (Fitria, 2020; Pitri, 2018; Ramadhan, 2020; Siti Nurhayati, 2020; Wasiso \& Winarsih, 2020). Apabila materi pembelajaran tidak tersampaikan secara maksimal, maka tujuan pembelajaran tidak tercapai dan akan berdampak pada hasil belajar hingga kualitas pendidikan akan menurun.

Solusi yang sudah dilakukan pada penelitian sebelumnya, sistem pembelajaran e-learning mampu memberikan dampak positif terhadap proses pembelajaran. Pembelajaran e-learning mampu mengefektifkan pembelajaran serta meningkatkan hasil belajar peserta didik (Alsalhi et al., 2019; Berga et al., 2021; Grønlien et al., 2021; Kacetl \& Semradova, 2020; Khodeir, 2018; Kusuma et al., 2020; Müller \& Mildenberger, 2021; Pamungkas \& Sartika, 2021). Namun yang menjadi permasalahannya adalah model pembelajaran yang digunakan hanya sebatas diskusi, pemberian materi, serta pengerjaan tugas. Beranjak dari hal tersebut, dianggap perlu adanya model pembelajaran yang sesuai dengan karasteristik mata pelajaran dan dikolaborasikan dengan pembelajaran e-learning. Pembelajaran e-learning berbasis discovery learning mampu menciptakan proses pembelajaran jarak jauh yang lebih banyak memberikan kesempatan kepada peserta didik untuk menemukan materinya secara mandiri. Model pembelajaran discovery learning dapat mengembangkan cara belajar aktif dengan menemukan sendiri dan menyelidiki sendiri. Dengan demikian, hasil yang akan diperoleh bertahan lama dalam ingatan, sehingga tidak mudah dilupakan oleh siswa (Firosalia Kristin, 2019). Berdasarkan beberapa penelitian yang dilakukan sebelumnya di SD, SMP, SMA, hingga perguruan tinggi ditemukan bahwa penerapan model pembelajaran discovery learning dinyatakan berhasil meningkatkan minat dan hasil belajar siswa di kelas. Namun pada penelitian sebelumnya terkait model pembelajaran discovery learning hanya dilakukan secara tatap muka (Ana, 2018; Rahmayani, 2019; Simatupang, 2020).

Beranjak dari permasalahan tersebut perlu adanya pembelajaran e-learning berbasis discovery learning pada mata pelajaran Sejarah kelas X. Selain tidak terbatas oleh ruang dan waktu, dengan menggunakan model pembelajaran e-learning berbasis discovery learning siswa lebih banyak berperan aktif dalam proses pembelajaran. Materi pelajaran tidak disajikan secara utuh melainkan siswa dituntut menemukan sendiri materi yang dibutuhkan, sehingga materi yang dipelajari siswa akan bertahan lebih lama dalam ingatan dan tidak mudah dilupakan. Dengan adanya pengembangan sistem pembelajaran $e$ learning berbasis discovery learning ini diharapkan dapat mengoptimalkan proses pembelajaran yang ada di kelas X. Dengan adanya pengembangan sistem media E-learning dikolaborasikan dengan model pembelajaran discovery learning pada mata pelajaran Sejarah, siswa tidak harus selalu bertatap muka dengan guru. Selain menggunakan media online, siswa juga dapat mencari materi dari berbagai sumber yang ada. Berdasarkan pemaparan di atas, maka penelitian ini bertujuan untuk mengembangkan desain elearning berbasis discovery learning pada mata pelajaran Sejarah. 


\section{METODE}

Jenis penelitian ini adalah penelitian pengembangan. Produk yang dikembangkan berupa media e-learning berbasis discovery learning. Adapun model pengembangan yang digunakan adalah model ADDIE. Model pengembangan ini disusun dengan urutan kegiatan yang berkaitan dengan sumber belajar yang sesuai dengan kebutuhan dan karakteristik pembelajaran. Model pengembangan ADDIE terdiri atas lima langkah, yaitu analisis, perencanaan, pengembangan, implementasi, dan evaluasi (Marbun, 2021). Langkah-langkah yang dilakukan dalam pengembangan media E-learning berbasis discovery learning dengan menggunakan model ADDIE dijelaskan pada gambar 1 . Subjek yang digunakan untuk mengetahui validitas produk pengembangan pada penelitian ini yaitu: 1 ahli isi mata pelajaran, 1 ahli desain pembelajaran, 1 ahli media pembelajaran, 3 siswa untuk uji coba perorangan, dan 9 siswa untuk uji coba kelompok kecil.

Metode pengumpulan data pada penelitian pengembangan media e-learning berbasis discovery learning ini yaitu metode pencatatan dokumen dan metode kuesioner. Metode pencatatan dokumen adalah metode pengumpulan data dengan cara mengumpulkan segala macam dokumen dan melakukan pencatatan secara sistematis (Calang et al., 2017). Dokumen yang dikumpulkan pada metode pencatatan dokumen ini adalah RPP mata pelajaran Sejarah, silabus, materi bahan ajar Sejarah kelas X, dan rekapan nilai kelas X pada mata pelajaran Sejarah. Metode pengumpulan data berikutnya adalah metode kuesioner. Metode kuesioner adalah cara mengumpulkan data dengan mengirimkan daftar pertanyaan atau pernyataan kepada subjek penelitian (Calang et al., 2017). Pada metode kuesioner dilakukan review media oleh ahli isi bidang studi atau mata pelajaran, ahli desain pembelajaran, dan siswa uji coba perorangan, dan uji coba kelompok kecil.

Aspek-aspek penilaian dan evaluasi media yang pada saat review media adalah sebagai berikut. Pada instrumen uji ahli materi, aspek-aspek yang dijadikan penilaian media yang dibuat adalah sebagai berikut. Pertama, aspek kurikulum terdiri dari identitas, kompetensi dasar, indikator, dan tujuan pembelajaran. Kedua, aspek materi terdiri dari sistematika penulisan materi dan keluasan pendalaman materi. Ketiga, aspek kalimat/ bahasa terdiri dari kejelasan kalimat dan kejelasan penggunaan bahasa. Ke-empat aspek evaluasi terdiri dari kejelasan rumus soal, dan tingkat kerumitan soal sesuai dengan kompetensi (Agustini \& Ngarti, 2020). Pada instrument uji ahli desain pembelajaran terdapat empat aspek yang dijadikan bahan penilaian yaitu aspek desain materi, pembelajaran, dan evaluasi. Dari keempat aspek tersebut dijabarkaan lagi menjadi beberapa komponen. Pertama, aspek desain terdiri dari judul, model, dan langkah-langkah pembelajaran. Kedua, aspek materi terdiri dari kejelasan petunjuk belajar, kejelasan uraian materi, sistematika penyajian materi, kesesuaian gambar dengan materi, dan kesesuaian video dengan materi. Ketiga, aspek pembelajaran adalah bagaimana media mampu memotivasi siswa belajar. Keempat aspek evaluasi adalah bagaimana kejelasan petunjuk pengerjaan soal (Agustini \& Ngarti, 2020).

Pada instrumen uji ahli media pembelajaran terdapat tiga aspek yang dijadikan bahan penilaian yaitu aspek tampilan, interaktivitas media, dan kemanfaatan. Dari ke-tiga aspek tersebut dijabarkaan lagi menjadi beberapa komponen. Pertama, aspek tampilan terdiri dari ketepatan jenis dan ukuran (huruf dan angka), warna teks, spasi, layout, komposisi warna tampilan, kejelasan gambar, kualitas video, fungsi navigasi, konsistensi navigasi, memotivasi belajar siswa. Kedua, aspek interaktivitas terdiri dari kemudahan pengoperasian dan kelengkapan fasilitas belajar. Ketiga, aspek kemanfaatan terdiri dari focus perhatian dan kemudahan proses belajar (Mustakim, 2020). Pada instrumen uji perorangan dan kelompok kecil terdapat tiga aspek yang dijadikan bahan penilaian yaitu aspek media, materi, dan manfaat. Dari ketiga aspek tersebut dijabarkaan lagi menjadi beberapa komponen. Pertama, aspek media terdiri dari tampilan media, kemudahan penggunaan, dan kemenarikan media. Kedua, aspek materi terdiri dari keterbacaan, bahasa, kesesuaian materi, dan relevansi soal. Ketiga, aspek manfaat adalah media mampu memotivasi belajar (Mustakim, 2020). Setelah instrumen dibuat kemudian intrumen dinilai oleh ahli (judges) yang memiliki keahlian variable yang dikembangkan. Sesudah mendapatkan review dari ahli (judges) kemudian didapatkan validitas isi yang diisyaratkan dan dianalisis dengan rumus Gregoy dengan mekanisme yaitu: "pakar yang melakukan penilaian instrumen mengklarifikasi butir instrumen, hasil penilaian pakar ditabulasi dalam bentuk matrik, dibuat tabulasi silang, dan dilakukan penghitungan validitas isi"(Arlini et al., 2017).

Penelitian pengembangan ini menggunakan dua metode analisis data, yaitu analisis deskriptif kualitatif dan analisis deskriptif kuantitatif. Metode kualitatif digunakan sebagai pengolah data hasil masukan dari ahli isi mata pelajaran, ahli desain pembelajaran, ahli media pembelajaran, uji coba perorangan, dan uji coba kelompok kecil. Hasil analisis yang diperoleh digunakan sebagai bahan revisi dan pengembangan produk yang diteliti. Metode kuantitatif digunakan untuk mengolah data yang diperoleh melalui angket dalam bentuk deskriptif persentase. Untuk dapat memberikan masukan dan pengambilan keputusan terhadap hasil angket atau kuesioner, maka digunakan ketetapan Konversi Tingkat Pencapaian Skala 5 seperti pada Tabel 1 . 
Tabel 1. Konversi PAP Tingkat Pencapaian dengan Skala 5

\begin{tabular}{cccc}
\hline No & Tingkat Pencapaian & Kualifikasi & Keterangan \\
\hline 1 & $90-100$ & Sangat Baik & Tidak Perlu Direvisi \\
2 & $75-89$ & Baik & Sedikit Direvisi \\
3 & $65-74$ & Cukup & Direvisi Secukupnya \\
4 & $55-64$ & Kurang & Banyak Hal Yang Direvisi \\
5 & $0-54$ & Sangat Kurang & Diulangi Membuat Produk \\
\hline
\end{tabular}

\section{HASIL DAN PEMBAHASAN}

Hasil

Tahap Analisis (Analysis), dalam menganalisis kebutuhan peserta didik perlu dibuatkan sebuah instrumen untuk mengetahui kebutuhan peserta didik. Cara yang digunakan untuk menganalisis kebutuhan peserta didik adalah wawancara. Hasil wawancara dapat menjadi dasar untuk menentukan pemecahan masalah yang dialami dalam proses pembelajaran. Hasil wawancara dengan guru serta observasi yang dilakukan di sekolah dapat dijadikan sebagai acuan pengembang untuk menentukan pemecahan masalah yang terjadi. Adapun hal yang ditekankan dalam analisis ini adalah untuk mengetahui kompetensi yang dituntut kepada peserta didik, karakteristik peserta didik tentang kapasitas belajarnya dan untuk mengetahui materi atau bahan ajar yang digunakan dalam pembelajaran sesuai dengan tuntutan kompetensi.

Tahap Desain (Design), meliputi memilih dan menetapkan perangkat lunak yang akan digunakan untuk mengembangkan media e-learning berbasis discovery learning, membuat Flowchart dan Storyboard, menyususn instrument penilaian, yang terdiri dari pertama perangkat lunak/software yang digunakan dalam pengembangan media ini adalah browser (google chrome) Microsoft Word, Microsoft Powerpoint, Adobe Photoshop, Filmora, Format Factory, Corel Draw, dan kine master, kedua Flowchart digunakan sebagai gambaran alur kerja dari e-learning. Tujuan pembuatan flowchart ialah untuk mempermudah memahami alur kerja dari e-learning yang akan dikembangkan. Tahap selanjutnya adalah menyusun instrumen penilaian e-learning dari instrumen yang telah digunakan untuk mengetahui validitas produk yang sudah dikembangkan terlebih dahulu harus diujikan butir oleh dua dosen yang berkompeten di bidangnya. Kuesioner yang diuji validitasnya yaitu ahli isi mata pelajaran, ahli desain pembelajaran, ahli media pembelajaran, uji coba perorangan, dan uji coba kelompok kecil. Validasi instrumen atau validasi produk dilakukan oleh dua dosen.

Tahap Pengembangan (Development), langkah selanjutnya adalah melakukan tahap pengembangan yaitu pembuatan media e-learning dan beberapa konten pendukung. Tahap pengembangan e-learning berbasis discovery learning ini dikembangkan menjadi produk yang seutuhnya. Dalam kegiatan yang pertama dilakukan pada pengembangan ini adalah pembuatan desain halaman awal class menggunakan photoshop dan word. Dalam halaman awal kelas ini terdapat empat pilihan halaman. Mulai dari manfaat belajar sejarah (sebagai stimulus siswa) dan halaman pertemuan satu sampai pertemuan tiga. Tampilan pada halaman utama ditunjukan pada Gambar 1.

Pada halaman pertemuan pertama terdapat enam point yang bisa diakses oleh siswa. Pertama, tersedia adalah Rencana Pelaksanaan Pembelajaran e-learning yang sudah disesuaikan dengan pembelajaran online, sehingga guru maupun siswa bisa melaksanakan pembelejaran online dengan baik dan benar, sesuai dengan pakem yang ada pada RPP. Kedua, tersedia petunjuk atau langkah-langkah pembelajaran yang dapat dijadikan pedoman dalam melakukan pembelajaran online. Ketiga, materi tentang sejarah singkat terkait materi yang akan dipelajari yang menggunakan video sebagai stimulus respon agar dapat menumbuhkan ketertarikan siswa terhadap materi yang akan dipelajari. Keempat, materi "Sejarah peradaban nenek moyang bangsa Indonesia" yang sudah didesain sedemikian rupa dengan beberapa penambahan gambar penunjang dan disajikan dalam bentuk PDF. Kelima, terdapat forum sesi diskusi, yang nantinya dapat dijadikan sebagai platform guru untuk berinteraksi dengan siswa. Misalnya, pemberian apresiasi, motivasi, dan sesi tanya jawab dengan siswa yang belum sepenuhnya memahami materi yang dipelajari. Keenam, platform ini terdapat beberapa soal yang digunakan sebagai alat pengukur pemahaman siswa terkait materi yang sudah dipelajari. Tampilan pada halaman pertemuan pertama ditunjukan pada Gambar 2. 


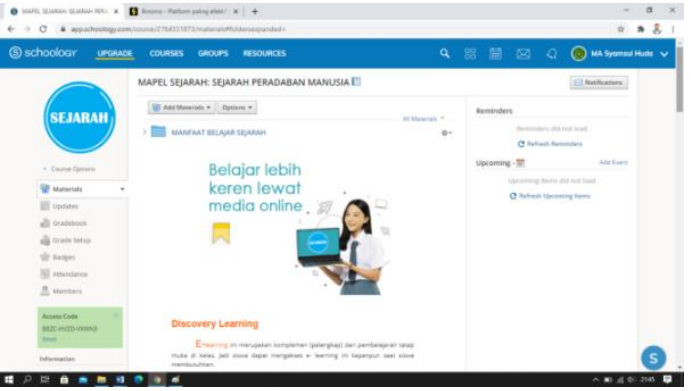

Gambar 1. Halaman awal e-learning

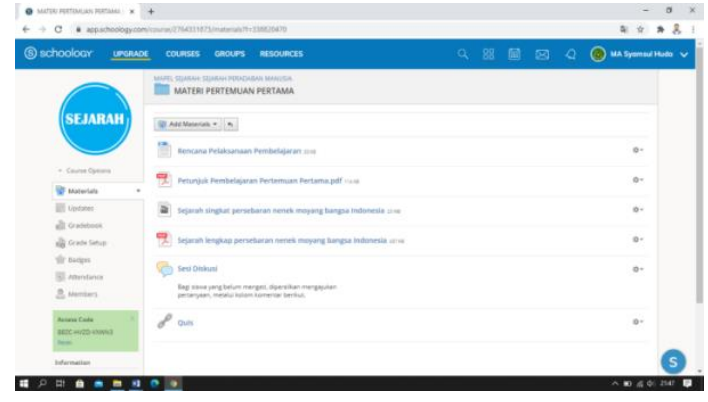

Gambar 2. Halaman pertemuan pertama

Tahap Implementasi (Implementation) Pada tahap implementasi dilakukan uji validitas produk meliputi: uji coba ahli media pembelajaran, ahli desain pembelajaran, ahli isi mata pelajaran, uji coba perorangan dan uji coba kelompok kecil. Hasil validitas pengembangan e-learning berbasis discovery learning secara keseluruhan mendapatkan persentase baik dan layak untuk diterapkan. Persentase validitas produk e-learning berbasis discovery learning dipaparkan pada Table 2.

Tabel 2. Persentase Validitas Produk

\begin{tabular}{clcc}
\hline No & Subjek Uji Coba & Hasil Validitas (\%) & Kualifikasi \\
\hline 1 & Uji Ahli isi Mata Pelajaran & $91 \%$ & Sangat Baik \\
2 & Uji ahli Desain pembelajaran & $83 \%$ & Baik \\
3 & Uji ahli media pembelajaran & $92 \%$ & Sangat Baik \\
4 & Uji Coba Perorangan & $95 \%$ & Sangat Baik \\
5 & Uji Coba Kelompok Kecil & $93 \%$ & Sangat Baik \\
\hline
\end{tabular}

E-learning berbasis discovery learning ini dinyatakan valid dengan: (a) Hasil review ahli isi mata pelajaran yang menunjukkan e-learning berbasis discovery learning mendapatkan predikat sangat baik (91\%). (b) Hasil review ahli desain pembelajaran menunjukkan bahwa e-learning berbasis discovery learning ini mendapatkan predikat baik yaitu (83\%). (c) Hasil review dari ahli media pembelajaran menunjukkan e-learning berbasis discovery learning ini mendapatkan predikat sangat baik (92\%). (d) Hasil review dari uji perorangan menunjukkan bahwa e-learning berbasis discovery learning ini mendapatkan predikat sangat baik yaitu (95\%). (e) hasil review dari uji kelompok kecil menunjukkan $e$ learning berbasis discovery learning ini mendapatkan predikat sangat baik (93\%). Hasil dari validitas pengembangan e-learning berbasis discovery learning secara keseluruhan mendapatkan persentase baik.

Tahap Evaluasi (Evaluation) Evaluasi dilakukan melalui dua tahap yaitu evaluasi formatif. Evaluasi formatif dilakukan untuk memperbaiki produk yang dihasilkan. Berdasarkan persentase yang diperoleh terdapat beberapa masukan dan saran yang digunakan sebagai bahan pertimbangan dalam menyempurnakan produk yang dikembangkan. Masukan dan saran yang diperoleh adalah sebagai berikut. Berdasarkan masukan yang diberikan oleh ahli desain pembelajaran, masukan yang diberikan dipertimbangkan dan digunakan untuk menyempurnakan pembelajaran dengan konten e-learning. Masukan dari ahli desain pembelajaran ialah pada urutan kegiatan pembelajaran, alangkah baiknya jika dilakukan sesi diskusi terlebih dahulu daripada soal atau quis. Berdasarkan masukan yang diberikan oleh ahli meadia pembelajaran. Masukan yang diberikan dipertimbangkan dan digunakan untuk menyempurnakan pembelajaran dengan konten e-learning. Masukan dari ahli media pembelajaran ialah pada setiap judul pertemuan ditulis dengan huruf kapital. Berdasarkan hasil uji coba perorangan dan uji coba kelompok kecil diketahui bahwa konten e-learning berada pada kualifikasi sangat baik. Kualifikasi sangat baik ini diperoleh karena media e-learning yang disajikan dapat meningkatkan minat dan motivasi belajar siswa. Setelah dilakukan beberapa perbaikan produk e-learning berbasis discovery learning, maka produk sudah dinyatakan valid. Hasil pengembangan produk e-learning berbasis discovery learning, disajikan pada Gambar 3 dan 4. 


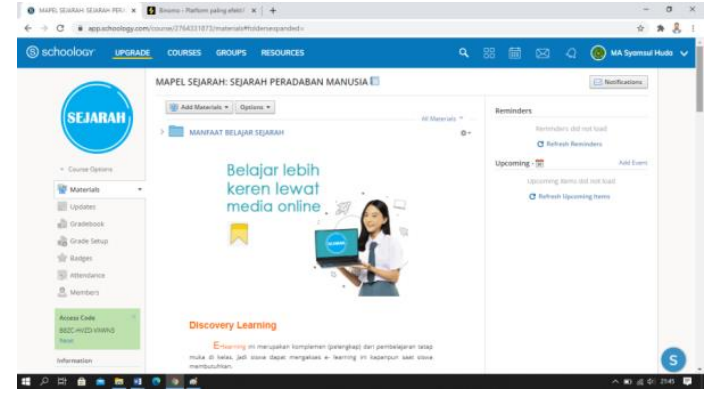

Gambar 3. Halaman awal e-learning

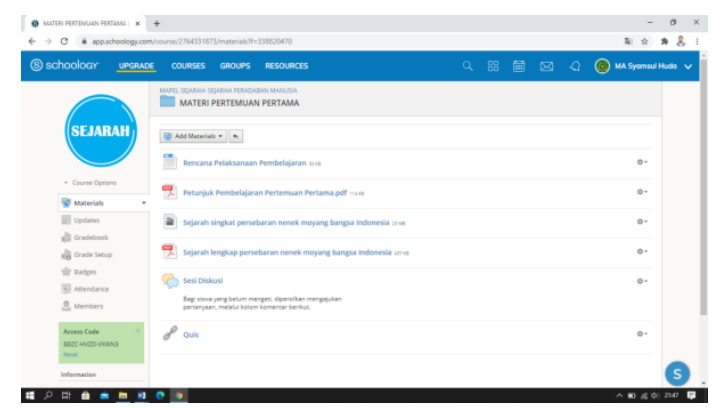

Gambar 4. Halaman pertemuan pertama e-learning

\section{Pembahasan}

Dalam proses pengembangan media e-learning berbasis discovery learning diggunakan model pengembangan ADDIE. Hal ini berimplikasi pada keefektifan baik proses maupun waktu pengembangan. Berdasarkan hasil yang diperoleh pada uji validitas, media e-learning berbasis discovery learning mendapatkan kualifikasi sangat baik. Terdapat beberapa unsur penting yang menjadikan media ini mencapai kualifikasi sangat baik. Unsur yang dimaksud adalah sebagai berikut. Pertama, penyusunan materi pada media e-learning berbasis discovery learning harus merujuk pada silabus dan buku bahan ajar yang relevan. Fungsi utama media pembelajaran adalah sebagai alat bantu mengajar yang turut memengaruhi iklim, kondisi dan lingkungan belajar, yang ditata dan diciptakan oleh guru dengan memperhatikan uraian materi dan sistematika penyajian materi yang benar (Wijayanti \& Hartati, 2018). Oleh sebab itu, sudah menjadi keharusan bahwa media harus didasarkan dari kebutuhan materi bagi siswa yang membutuhkan. Kedua, soal-soal pada media e-learning berbasis discovery learning harus mampu mengukur capaian dari tujuan pembelajaran. Soal evaluasi ini disusun untuk mengukur capaian belajar siswa, sehingga diketahui pemahaman siswa terhadap materi yang dipelajarinya. Ketiga, materi dalam media diuraikan secara jelas, sistematis sesuai dengan alur belajar siswa. Memetakan dan mengorganisasikan materi pembelajaran sangat penting sebagai upaya dalam menentukan dan mengelompokkan materi pembelajaran ke dalam pokok bahasan, subpokok bahasan, dan pokok materi sesuai dengan capaian pembelajaran yang telah ditentukan (Darma et al., 2020). Melalui pemetaan ini, siswa akan lebih mudah dalam mengikuti alur belajar dan berimplikasi pada kemudahan dalam memahami materi pelajaran. Keempat, media dikemas dengan menyajikan kemudahan dalam akses sumber dan proses pembelajaran. Hal ini akan mampu memotivasi siswa dalam pembelajaran serta mampu meningkatkan minat belajar. Pemanfaatkan media pembelajaran e-learning dalam proses pembelajaran akan mengubah cara belajar siswa, Siswa yang biasanya hanya mendengarkan akan menjadi lebih aktif dalam mengakses materi pelajaran kapan pun dan di mana pun, sehingga dapat memengaruhi minat belajar siswa menjadi lebih baik lagi (Suartama, 2021). Kelima, media e-learning menyediakan aktivitas untuk meningkatkan interaktivitas pembelajaran secara online. Pemilihan dan penentuan aktivitas belajar yang terkonsep menjadi satu alur belajar yang menarik dan interaktif serta sesuai dengan tujuan pembelajaran, yaitu mampu meningkatkan minat belajar siswa (Oknisih, N., \& Suyoto, 2019; Tu et al., 2020). Keenam, ketepatan pemilihan media dengan permasalahan yang dihadapi. Permasalahan yang dihadapi selama pandemi covid-19 saat ini adalah terbatasnya proses pembelajaran secara tatap muka serta tidak efektifnya proses belajar yang berlangsung selama ini. Hal ini sangat membutuhkan sarana belajar yang mampu mengakomodasi fleksibilitas proses belajar siswa, baik dari segi waktu maupun strategi penyampaian materinya. Melalui e-learning, proses dan waktu belajar mampu dioptimalkan, sehingga hal ini dapat meningkatkan prestasi akademik siswa (Nácher et al., 2021). Berkenaan dengan hal tersebut, menggunakan media e-learning berbasis discovery learning tidak hanya dapat mengoptimalkan proses dan waktu belajar siswa. Dengan adanya penanaman model discovery learning siswa juga dituntut untuk dapat melatih keterampilan berpikir tingkat tinggi, sehingga akan dapat mampu semakin mengoptimalkan proses pembelajaran siswa.

Berdasarkan pembahasan di atas, media e-learning berbasis discovery learning yang dikembangkan digunakan dalam proses pembelajaran Sejarah kelas X dengan tujuan agar mampu mengatasi kurangnya waktu pembelajaran serta meningkatkan minat belajar siswa pada mata pelajaran Sejarah kelas X. Dengan demikian hasil belajar siswa dapat ditingkatkan. Namun, media e-learning berbasis discovery learning ini masih memiliki kekurangan yaitu implementasi baru dilakukan dalam skala uji formatif (uji coba perorangan dan kelompok kecil) untuk mengukur kelayakan implementasi. Di samping itu, belum dilakukan uji lebih lanjut untuk mengukur efektivitas penggunaan media, sehingga pengaruhnya secara signifikan dalam proses dan hasil pembelajaran belum terukur secara baik mengingat pandemi Covid-19 yang saat ini terjadi. Dengan adanya pengembangan sistem pembelajaran E-learning 
berbasis discovery learning ini diharapkan dapat mengoptimalkan proses pembelajaran yang ada di kelas X MA Syamsul Huda Buleleng tahun pelajaran 2020/2021. Dengan adanya pengembangan sebuah sistem pembelajaran E-learning berbasis discovery learning pada mata pelajaran Sejarah ini, siswa tidak harus selalu bertatap muka dengan guru. Selain menggunakan media online, siswa juga dapat mencari materi dari berbagai sumber yang ada di internet dan di lingkungan sekitarnya karena model pembelajaran discovery learning lebih menekankan proses pembelajaran pada siswa dengan menemukan sendiri materi yang dipelajarinya

\section{SIMPULAN}

Media e-learning berbasis discovery learning dinyatakan layak untuk digunakan dalam proses pembelajaran Sejarah kelas X. Pada pembuatan media e-learning berbasis discovery learning penyusunan materinya merujuk pada silabus dan buku bahan ajar. Selain itu, materi yang terdapat pada media sudah sesuai dengan materi pelajaran dan mampu memudahkan dalam proses pembelajaran serta mampu meningkatkan minat belajar.

\section{DAFTAR PUSTAKA}

Agustini, K., \& Ngarti, J. G. (2020). Pengembangan Video Pembelajaran untuk Meningkatkan Motivasi Belajar Siswa Menggunakan Model R \& D. Jurnal Ilmiah Pendidikan Dan Pembelajaran, 4(April 2020), 62-78. https://ejournal.undiksha.ac.id/index.php/JIPP/article/download/18403/14752.

Ali, S., Hafeez, Y., Humayun, M., Jamail, N. S. M., Aqib, M., \& Nawaz, A. (2021). Enabling Recommendation System Architecture in Virtualized Environment for E-Learning. Egyptian Informatics Journal, xxxx. https://doi.org/10.1016/j.eij.2021.05.003.

Alsalhi, N. R., Eltahir, M. E., \& Al-Qatawneh, S. S. (2019). The Effect of Blended Learning on the Achievement of Ninth Grade Students in Science and Their Attitudes towards Its Use. Heliyon, 5(9), e02424. https://doi.org/10.1016/j.heliyon.2019.e02424. Ana, N. Y. (2018). Penggunaan Model Pembelajaran Discovery Learning dalam Peningkatan Hasil Belajaran Siswa Di Sekolah Dasar. Pedagogi: Jurnal Ilmu Pendidikan, 56. https: //doi.org/10.24036/fip.100.v18i2.318.000-000.

Apdelmi, A. (2019). Penerapan Model Pembelajaran Listening Team untuk Disiplin Siswa pada Mata Pelajaran Sejarah di SMA Negeri 2 Kerinci. HISTORIA: Jurnal Program Studi Pendidikan Sejarah, 4(1), 58-68. https://doi.org/10.33373/j-his.v4i1.1723.

Arlini, H., Humairah, N., \& Sartika, D. (2017). Penerapan Model Pembelajaran Kooperatif Tipe Think Pair Share dengan Teknik Advance Organizer. Saintifik, 3(2), 182-189. https://doi.org/10.31605/saintifik.v3i2.163.

Berga, K. A., Vadnais, E., Nelson, J., Johnston, S., Buro, K., Hu, R., \& Olaiya, B. (2021). Blended Learning Versus Face-to-Face Learning in an Undergraduate Nursing Health Assessment Course: A QuasiExperimental Study. Nurse Education Today, 96(October 2020), 104622. https://doi.org/10.1016/j.nedt.2020.104622.

Calang, P. N., Jaya, K. A., \& Aceh, P. (2017). Fakultas Hukum Universitas Syiah Kuala. 1(5), 1-16.

Darma, I. K., Karma, I. G. M., \& Santiana, I. M. A. (2020). Blended Learning, Inovasi Strategi Pembelajaran Matematika di Era Revolusi Industri 4.0 bagi Pendidikan Tinggi. Prosiding Seminar Nasional Pendidikan Matematika, 3, 527-539.

Firosalia Kristin. (2019). Analisis Model Pembelajaran Discovery Learning dalam Meningkatkan Hasil Belajar IPA-Biologi. Talenta Conference Series: Science and Technology (ST), 2(2). https://doi.org/10.32734/st.v2i2.532.

Fitria. (2020). Meningkatkan Hasil Pembelajaran Sejarah Indonesia dengan Metode Diskusi Terbimbing pada Siswa Kelas X Tsm 1 di SMK Negeri 1 Gunung Jati Kabupaten Cirebon Yana. Meningkatkan Hasil Pembelajaran Sejarah Indonesia dengan Metode Diskusi Terbimbing pada Siswa Kelas X Tsm 1 Di SMK Negeri 1 Gunung Jati Kabupaten Cirebon Yana, 1(3), 1689-1699.

Grønlien, H. K., Christoffersen, T. E., Ringstad, Ø., Andreassen, M., \& Lugo, R. G. (2021). A Blended Learning Teaching Strategy Strengthens the Nursing Students' Performance and Self-Reported Learning Outcome Achievement in an Anatomy, Physiology and Biochemistry Course - A QuasiExperimentalSstudy. Nurse Education in Practice, 52(March). https://doi.org/10.1016/j.nepr.2021.103046.

Kacetl, J., \& Semradova, I. (2020). Reflection on Blended Learning and E-Learning - Case Study. Procedia Computer Science, 176, 1322-1327. https://doi.org/10.1016/j.procs.2020.09.141.

Khodeir, L. M. (2018). Blended Learning Methods as an Approach to Teaching Project Management to 
Architecture Students. Alexandria Engineering Journal, 57(4), 3899-3905. https://doi.org/10.1016/j.aej.2018.10.004.

Kusuma, A. A. I. R. S., Santosa, M. H., \& Myartawan, I. P. N. W. (2020). Exploring the Influence of Blended Learning Method in English Recount Text Writing for Senior High School Students. Journal of English Teaching, 6(3), 193-203. https://doi.org/https://doi.org/10.33541/jet.v6i3.1913.

Marbun, P. (2021). Disain Pembelajaran Online pada Era dan Pasca Covid-19. CSRID (Computer Science $\begin{array}{lllll}\text { Research and Its Development } & 129 .\end{array}$ https: //doi.org/10.22303/csrid.12.2.2020.129-142.

Mitra, N. K., Aung, H. H., Kumari, M., Perera, J., Sivakumar, A., Singh, A., \& Nadarajah, V. D. (2021). Improving the Learning Process in Anatomy Practical Sessions of Chiropractic Program Using ELearning Tool. Translational Research in Anatomy, 23, 100100. https: //doi.org/10.1016/j.tria.2020.100100.

Müller, C., \& Mildenberger, T. (2021). Facilitating Flexible Learning by Replacing Classroom Time With an Online Learning Environment: A Systematic Review of Blended Learning in Higher Education. Educational Research Review, 100394. https://doi.org/10.1016/j.edurev.2021.100394.

Mustakim, M. (2020). Efektivitas Pembelajaran Daring Menggunakan Media Online Selama Pandemi Covid-19 pada Mata Pelajaran Matematika. Al Asma: Journal of Islamic Education, 2(1), 1. https: //doi.org/10.24252/asma.v2i1.13646.

Nácher, M. J., Badenes-Ribera, L., Torrijos, C., Ballesteros, M. A., \& Cebadera, E. (2021). The Effectiveness of the GoKoan E-Learning Platform in Improving University Students' Academic Performance. Studies in Educational Evaluation, 70. https://doi.org/10.1016/j.stueduc.2021.101026.

Nursulistyo, E. D., Siswandari, S., \& Jaryanto, J. (2021). Model Team-Based Learning dan Model ProblemBased Learning secara Daring Berpengaruh terhadap Kemampuan Berpikir Kritis Siswa. Mimbar Ilmu, 26(1), 128. https://doi.org/10.23887/mi.v26i1.32321.

Oknisih, N., \& Suyoto, S. (2019). Alur Belajar: Meningkatkan Interaktivitas Pembelajaran Daring. Seminar \& Lokakarya Pembelajaran Daring Di Perguruan Tinggi, September, 1-10. https://www.researchgate.net/publication/323676111_Alur_Belajar_Meningkatkan_Interaktivita s_Pembelajaran_Daring.

Pamungkas, A. S., \& Sartika, S. B. (2021). The Role of Primary School Teachers on Online Learning with WhatsApp Group. 5(1), 77-86.

Pitri, A. (2018). Pengaruh Penerapan Model Pembelajaran Discovery Learning terhadap Hasil Belajar Peserta Didik Kelas V SD. Journal of Chemical Information and Modeling, 6(1), 1-84.

Rahmayani, A. (2019). Pengaruh Model Pembelajaran Discovery Learning terhadap Hasil Belajar Siswa. Jurnal Pendidikan Dan Kewirausahaan, 7(1), 93-108. https://doi.org/10.47668/pkwu.v7i1.20.

Ramadhan, O. M. (2020). Jurnal Inovasi Pembelajaran (JINoP). Efektivitas Pembelajaran Sejarah Kebudayaan Islam Melalui Google Classroom Ditinjau dari Hasil Belajar Siswa, 6(2), 204-214. https://doi.org/10.22219/jinop.v1i1.2441.

Simatupang, B. A. (2020). Students 'Perception of $t$ he Discovery Learning Strategy in Learning Reading Comprehension at Widya Manggala Senior High School. 6(June), 158-172.

Siti Nurhayati. (2020). Upaya Meningkatkan Hasil Belajar Sejarah Siswa SMAN 1 Pandeglang dengan Menggunakan Model Pembelajaran Kreatif dan Produktif. Jurnal Kajian Pendidikan Dan Pengajaran, 6(1), 14-22. https://doi.org/10.30653/003.202061.92.

Suartama, I. K. (2021). Mobile Ubiquitous Learning : Strategi untuk Melibatkan Siswa dalam Pembelajaran Online yang Bermakna (Issue January).

Tu, L., Wahyuni, S., Japa, I. G. N., \& Rati, N. W. (2020). Correlation of Reading Interests and Learning Motivation Toward Science Learning Outcomes. 4(3), 484-495.

Ulfah, U. M., \& Lukiastuti, F. (2018). Pengaruh Kompetensi dan Independensi pada Kinerja Auditor Internal Pemerintah dengan Etika Auditor sebagai Variabel Moderasi (Studi Pada Inspektorat Kabupaten Tegal). Jurnal Manajemen Teori Dan Terapan / Journal of Theory and Applied Management, 11(1), 39. https://doi.org/10.20473/jmtt.v11i1.7620.

Wasiso, A. J., \& Winarsih, S. M. (2020). Pengaruh Model Pembelajaran dan Sikap Sosial terhadap Hasil Belajar Sejarah SMA Negeri 24 Kabupaten Tangerang. Pengaruh Model Pembelajaran Dan Sikap Sosial Terhadap Hasil Belajar Sejarah Siswa SMA Andrian, 13(1), 31-40. https://doi.org/10.21831/jpipfip.v13i1.23590.

Wijayanti, P. D., \& Hartati, L. (2018). Pengembangan Modul Matematika SMK Teknologi Kelas X Semester Ganjil Terintegrasi Pendidikan Karakter Bangsa. Jurnal Penelitian Dan Pembelajaran Matematika, 11(2), 157-168. https://doi.org/10.30870/jppm.v11i2.3762. 